\title{
How Investor Perceptions Drive Actual Trading and Risk-Taking Behavior
}

\author{
Arvid O. I. Hoffmann, Thomas Post, and Joost M. E. Pennings \\ Maastricht University
}

\begin{abstract}
Recent work in behavioral finance showed how investors' perceptions (i.e., return expectations, risk tolerance, and risk perception) affect hypothetical trading and risk-taking behavior. However, are such perceptions also capable of explaining actual trading and risktaking behavior? To answer this question, we combine monthly survey data with matching brokerage records to construct a panel dataset allowing us to simultaneously examine investor perceptions and behavior. We find that investor perceptions and changes therein are important drivers of actual trading and risk-taking behavior: Investors with higher levels of and upward revisions of return expectations are more likely to trade, have higher turnover, trade larger amounts per transaction, and use derivatives. Investors with higher levels of and upward revisions in risk tolerance are more likely to trade, have higher buy-sell ratios, use limit orders more frequently, and hold riskier portfolios. Investors with higher levels of risk perception are more likely to trade, have higher turnover, have lower buy-sell ratios, and hold riskier portfolios.
\end{abstract}

Keywords: Individual investors, Investment decisions, Investor perceptions, Trading behavior, Risk-taking behavior

\section{INTRODUCTION}

Investors' perceptions regarding the risk and return characteristics of a particular stock or the stock market are commonly assumed to be key drivers of their decision making (McInish and Srivastava [1984], Antonides and Van der Sar [1990]). Using choice experiments and investor surveys, recent work in behavioral finance showed how such investor perceptions are capable of explaining individuals' stock-market attitudes, hypothetical investment choices, self-reported willingness to invest in the stock market, or self-indicated risky asset portfolio composition (see, e.g., Wärneryd [1996], Weber and Milliman [1997], Keller and Siegrist [2006], Fellner and Maciejovsky [2007], Nosic and Weber [2010], Bateman et al. [2011], Weber, Weber, and Nosic [2013]). What is less known, however, is whether changes in these perceptions, such as individual investors' return expectations (i.e., investors' optimism about their portfolios' returns), risk

Address correspondence to Arvid O. I. Hoffmann, Assistant Professor of Finance, Maastricht University, School of Business and Economics, Department of Finance, P.O. Box 616, 6200 MD Maastricht, The Netherlands. E-mail: a.hoffmann@maastrichtuniversity.nl tolerance (i.e., investors' general attitude (like or dislike) toward financial risk), and risk perceptions (i.e., investors' interpretations of the riskiness of the stock market) are also capable of explaining actual trading and risk-taking decisions. It is not obvious that this is the case, as investors likely handle hypothetical choices and risks differently than real choices and risks, and actual decision making is typically more complex than hypothetical decision making in a lab setting (Slovic [1969], Kühberger, Schulte-Mecklenbeck, and Perner [2002]). As a result, an emerging stream of literature in behavioral finance starts to combine survey data with actual brokerage data to examine whether and how individual investors trade on their perceptions. In so doing, Guiso, Sapienza, and Zingales [2011], for example, report a negative association between investors' risk aversion and the ownership as well as portfolio share of risky assets. In a similar vein, Merkle and Weber [2014] document a positive association between investors' return expectations and their level of portfolio risk, and a negative association between investors' risk expectations and their level of portfolio risk. What is still unclear, however, is how individual investors' perceptions directly affect key aspects of their immediate trading and risk-taking behavior, such as the 
decision to trade or not, turnover, average trade size, buysell ratio, or limit order usage.

This paper contributes to the extant literature in behavioral finance by providing a comprehensive picture of the relationship between investor perceptions and investor decisions. That is, we analyze whether and how both the levels of and changes (month-to-month revisions) in investor perceptions drive their actual decision making. We combine monthly survey data with matching brokerage records to construct a panel data set allowing us to simultaneously examine the perceptions and behavior of individual investors. In particular, over a period of twelve months we measure individual investors' perceptions in a survey of their expectations for stock-market returns, as well as their risk tolerance and risk perceptions. ${ }^{1}$ In addition, we collect information on these investors' actual trading and risk-taking behavior through their brokerage records and match this information to the survey data.

Our results show that the levels of and changes in investor perceptions contribute significantly to understanding their actual trading and risk-taking decisions. In particular, we find that investors with higher levels and upward revisions of return expectations are more likely to trade, have higher turnover, trade larger amounts per transaction, and are more likely to use derivatives. Furthermore, we document that investors with higher levels of and upward revisions in risk tolerance are more likely to trade, have higher buy-sell ratios, use limit orders more frequently, and hold riskier portfolios as measured by the standard deviation of their portfolio's returns. Finally, we show that investors with higher levels of risk perception are more likely to trade, have higher turnover, have lower buy-sell ratios, and hold riskier portfolios.

This paper is organized as follows. The second section introduces the data. The third section presents empirical results on how perceptions affect trading and risk-taking decisions. Based on these results, the fourth section concludes by developing an overarching conceptual framework explaining how individual investors' perceptions impact key aspects of their trading and risk-taking decisions.

\section{DATA}

We base our analyses on a dataset first used by Hoffmann, Post, and Pennings [2013]. Hoffmann et al. examine how investor perceptions and behavior change during the financial crisis, but they do not focus on this paper's question of how perceptions drive behavior in the first place. The dataset consists of a combination of brokerage records of a sample of 1,510 clients of the largest discount broker in the Netherlands and matching monthly survey data obtained from these clients from April 2008 through March 2009. In contrast to retail-brokerage data, discount-brokerage data make it likely that the observed trading patterns, as well as the survey responses, reflect investors' own decision making and opinions and not those of an investment advisor. Moreover, discount brokers represent the dominant channel through which both U.S. and Dutch individuals invest in the stock market (Barber and Odean [2000], Bauer, Cosemans, and Eichholtz [2009]). As in Bauer et al., we exclude accounts of minors (age $<18$ years) and with an average end-of-month portfolio value (within the sample period) of less than 250. We also exclude professional traders by discarding accounts in the top $1 \%$ of annual trading volume, number of transactions, or turnover distributions, leaving 1,376 accounts for further investigation.

\section{Brokerage Records}

Brokerage records are available for investors who completed at least one survey during the sample period. A "record" consists of an identification number used to match clients' anonymized transaction records to their survey responses, a transaction date and time, a buy/sell indicator, the type of asset traded, the gross transaction value, and transaction commissions. The records also contain information on the market value of investors' daily account balances, demographics such as their age and gender, as well as their six-digit postal code. Based on this postal code, which is unique to each street (or parts of a street) in the Netherlands, and data retrieved from Statistics Netherlands (Central Bureau of Statistics), we impute investors' income and residential house value. ${ }^{2}$ Table 2 shows descriptive statistics of all brokerage accounts available, as well as those for the subset of accounts of clients who responded to the survey in each particular month of the sample period. Table 1 defines variables.

A comparison with samples used in other studies of individual investor behavior in the United States (Barber and Odean [2000]), Germany (Dorn and Huberman [2005]), and the Netherlands (Bauer et al. [2009]) shows that the sample is similar with regard to key characteristics, such as portfolio size, trading frequency, age, and gender composition. Comparing the average account value of the surveyed investors to the average account value of 50,000-60,000 for Dutch individual investors in general as estimated by the marketing research agency Millward-Brown (as reported in Bauer et al. [2009]) suggests that the average investor in the sample invests more than three-fourths of her total self-managed portfolio with this broker. More than $40 \%$ of survey respondents hold an investment account only with this particular broker. Of the respondents who also have accounts with other brokers, more than 50\% indicated that the other account(s) comprise(s) less than half their total investment portfolio. Hence, the sample seems sufficiently representative for the broader population of active and self-directed individual investors. 
TABLE 1

Variable Definitions

\begin{tabular}{|c|c|}
\hline Variable & Definition \\
\hline Gender & Indicator variable taking the value 0 for male investors and 1 for female investors. \\
\hline Age & Age of the investor in years as of April 2008. \\
\hline Account Tenure & Account tenure of the investor in years as of April 2008. \\
\hline Income & $\begin{array}{l}\text { Annual disposable income in } 2007 \text { (equals gross income minus taxes and social security contributions). Imputed for } \\
\text { each investor based on their 6-digit postal code. This postal code is unique for each street in the Netherlands. Data } \\
\text { source is the average net income per 6-digit postal code from Statistics Netherlands (Central Bureau of Statistics). }\end{array}$ \\
\hline Portfolio Value & Value of the investment assets in an investor's account at the end of the month. \\
\hline House Value & $\begin{array}{l}\text { Value of the house in 2008. Imputed for each investor based on their 6-digit postal code. This postal code is unique for } \\
\text { each street in the Netherlands. Data source is the average residential house value per 6-digit postal code from } \\
\text { Statistics Netherlands (Central Bureau of Statistics). }\end{array}$ \\
\hline Derivatives & $\begin{array}{l}\text { Indicator variable taking the value } 1 \text { if an investor traded an option or futures contract in a particular month or } 0 \\
\text { otherwise. }\end{array}$ \\
\hline Traded & Indicator variable taking the value 1 if an investor traded in a particular month or 0 otherwise \\
\hline Trades & Number of all executed transactions in a particular month. \\
\hline Volume & Sum of the absolute values of all purchases and sales in a particular month. \\
\hline Turnover & $\begin{array}{l}\text { Average of the absolute values of all purchases and sales in a particular month divided by the average of the portfolio } \\
\text { values at the beginning and end of a particular month. }\end{array}$ \\
\hline Dividend Choice Stock & $\begin{array}{l}\text { Indicator variable taking the value } 1 \text { if the investors' preferred way to receive dividend is stock dividend or } 0 \text { in case of } \\
\text { a preference for cash dividend. }\end{array}$ \\
\hline Dividend Choice Cash \& Stock & $\begin{array}{l}\text { Indicator variable taking the value } 1 \text { if the investors' preferred way to receive dividend is stock dividend for one of her } \\
\text { subaccounts and cash for another subaccount or } 0 \text { in case of a preference for cash dividend for all her subaccounts. }\end{array}$ \\
\hline Average Trade Size & The investor's monthly volume divided by her trades. \\
\hline Buy-Sell Ratio & $\begin{array}{l}\text { Difference between volume buy and volume sell, normalized (divided) by volume. For investors with no trades in a } \\
\text { particular month, this ratio is set to zero (such investors mimic an investor with equal buy and sell volume). }\end{array}$ \\
\hline Percent Limit Orders & Monthly fraction of all orders that are limit orders. \\
\hline Return & $\begin{array}{l}\text { Monthly investor return given by the product of the daily relative changes in the value of her portfolio after transaction } \\
\text { costs and portfolio in- and outflows. }\end{array}$ \\
\hline Return Expectation & $\begin{array}{l}\text { Reflects how optimistic a respondent is about her investment portfolio and its returns in the upcoming month. Details } \\
\text { on the survey questions are given in Table } 3 \text {. }\end{array}$ \\
\hline Risk Tolerance & $\begin{array}{l}\text { Reflects a respondent's general predisposition toward financial risk. Details on the survey questions are given in } \\
\text { Table } 3 \text {. }\end{array}$ \\
\hline Risk Perception & $\begin{array}{l}\text { Reflects a respondent's interpretation of how risky the stock market will be in the upcoming month. Details on the } \\
\text { survey questions are given in Table } 3 \text {. }\end{array}$ \\
\hline
\end{tabular}

Note. Due to data availability, the data retrieved from Statistics Netherlands refer to different years, that is, to 2007 for income and to 2008 for house value.

\section{Survey Design and Data Collection}

At the end of each month between April 2008 and March 2009 , we conducted an online survey among a panel of the broker's clients. To develop the panel, we sent an email invitation to 20,000 randomly selected clients in March 2008. Six months later, a re-invitation was sent to maintain a sufficient response rate. In the invitation email, clients were informed that their responses would be anonymous and that their data would be treated confidentially. The response rate to the first questionnaire (April 2008) was $4.28 \%$, which is in line with comparable large-scale investor surveys (see, e.g., Dorn and Sengmueller [2009]). A possible concern is that monthly variation of nonresponse (Table 2) might not be random. For example, age, account tenure, trading activity, and investment success could be related to the likelihood to respond to the survey. Robustness checks reported in Hoffmann et al. [2013], however, indicate that the data are unlikely to be affected by potential non-random response behavior related to these factors.
The survey elicited information on investors' expectations of stock-market returns, their risk tolerance, and their risk perceptions for the upcoming month (Table 3). In line with recent work in economic psychology (Kapteyn and Teppa [2011]), we use relatively simple subjective measures, because more complex objective measures are often misunderstood by respondents. Return expectations reflect the extent to which a respondent is optimistic about her investment returns and are measured similar to the subjective measure used in Weber et al. [2013]. Risk tolerance reflects a respondent's like or dislike of risky situations and is measured following Pennings and Smidts [2000]. Risk perception reflects a respondent's interpretation of the riskiness of the stock market and is measured according to Pennings and Wansink [2004].

To ensure reliable measurement, we used multiple items per variable, included these items in the survey in a random order, and used a mixture of regular and reverse-scored items (Netemeyer, Bearden, and Sharma [2003]). Cronbach's alpha is between 0.71 and 0.89 for the different 
TABLE 2

Descriptive Statistics (Panels A and B)

Panel A: All Brokerage Accounts

\begin{tabular}{|c|c|c|c|c|c|c|c|c|c|c|c|c|c|}
\hline Month & & Apr-08 & May-08 & Jun-08 & Jul-08 & Aug-08 & Sep-08 & Oct- 08 & Nov-08 & Dec-08 & Jan-09 & Feb-09 & Mar-09 \\
\hline Investors & $\mathrm{N}$ & 1,376 & 1,376 & 1,376 & 1,376 & 1,376 & 1,376 & 1,376 & 1,376 & 1,376 & 1,376 & 1,376 & 1,376 \\
\hline Gender & mean & 0.08 & 0.08 & 0.08 & 0.08 & 0.08 & 0.08 & 0.08 & 0.08 & 0.08 & 0.08 & 0.08 & 0.08 \\
\hline Age & mean & 50.56 & 50.56 & 50.56 & 50.56 & 50.56 & 50.56 & 50.56 & 50.56 & 50.56 & 50.56 & 50.56 & 50.56 \\
\hline Age & std & 13.57 & 13.57 & 13.57 & 13.57 & 13.57 & 13.57 & 13.57 & 13.57 & 13.57 & 13.57 & 13.57 & 13.57 \\
\hline Account Tenure & mean & 4.07 & 4.07 & 4.07 & 4.07 & 4.07 & 4.07 & 4.07 & 4.07 & 4.07 & 4.07 & 4.07 & 4.07 \\
\hline Account Tenure & std & 2.77 & 2.77 & 2.77 & 2.77 & 2.77 & 2.77 & 2.77 & 2.77 & 2.77 & 2.77 & 2.77 & 2.77 \\
\hline Income $€$ & mean & 20,242 & 20,242 & 20,242 & 20,242 & 20,242 & 20,242 & 20,242 & 20,242 & 20,242 & 20,242 & 20,242 & 20,242 \\
\hline Income $€$ & std & 4,314 & 4,314 & 4,314 & 4,314 & 4,314 & 4,314 & 4,314 & 4,314 & 4,314 & 4,314 & 4,314 & 4,314 \\
\hline Portfolio Value $€$ & mean & 52,854 & 52,695 & 44,872 & 42,840 & 45,963 & 37,688 & 31,127 & 30,100 & 30,679 & 29,564 & 26,514 & 27,875 \\
\hline Portfolio Value $€$ & std & $1,56,058$ & $1,56,096$ & $1,34,883$ & $1,27,338$ & $1,35,203$ & $1,17,935$ & $1,01,325$ & $1,04,663$ & $1,05,279$ & 99,322 & 91,598 & 92,307 \\
\hline House Value $€$ & mean & $2,78,982$ & $2,78,982$ & $2,78,982$ & $2,78,982$ & $2,78,982$ & $2,78,982$ & $2,78,982$ & $2,78,982$ & $2,78,982$ & $2,78,982$ & $2,78,982$ & $2,78,982$ \\
\hline House Value $€$ & std & $1,12,278$ & $1,12,278$ & $1,12,278$ & $1,12,278$ & $1,12,278$ & $1,12,278$ & $1,12,278$ & $1,12,278$ & $1,12,278$ & $1,12,278$ & $1,12,278$ & $1,12,278$ \\
\hline Fraction Derivatives & & 0.22 & 0.20 & 0.21 & 0.21 & 0.19 & 0.22 & 0.25 & 0.18 & 0.16 & 0.17 & 0.17 & 0.18 \\
\hline Fraction Traded & & 0.46 & 0.47 & 0.48 & 0.47 & 0.41 & 0.51 & 0.63 & 0.42 & 0.37 & 0.41 & 0.40 & 0.42 \\
\hline Trades (Traders) & mean & 8.57 & 7.54 & 7.71 & 9.24 & 7.16 & 8.72 & 10.60 & 8.83 & 7.81 & 9.64 & 8.87 & 10.13 \\
\hline Trades (Traders) & std & 11.38 & 11.15 & 12.44 & 16.75 & 10.63 & 13.06 & 16.65 & 13.10 & 12.04 & 14.66 & 14.86 & 17.75 \\
\hline Volume $€$ (Traders) & mean & 48,067 & 30,260 & 33,038 & 36,312 & 30,861 & 41,439 & 51,042 & 31,225 & 22,919 & 28,506 & 26,003 & 29,593 \\
\hline Volume $€$ (Traders) & std & $2,02,150$ & 70,839 & 95,236 & $1,13,827$ & 98,506 & $1,47,420$ & $2,75,317$ & $1,07,946$ & 63,888 & 78,723 & 77,374 & 97,800 \\
\hline Turnover (Traders) & mean & 0.55 & 0.46 & 0.42 & 0.60 & 0.46 & 0.62 & 0.99 & 0.73 & 0.61 & 0.80 & 0.67 & 0.78 \\
\hline Turnover (Traders) & std & 1.53 & 1.22 & 1.12 & 1.85 & 1.41 & 1.87 & 3.63 & 1.82 & 1.82 & 2.77 & 2.49 & 2.46 \\
\hline $\begin{array}{l}\% \text { Limit Orders } \\
\text { (Traders) }\end{array}$ & mean & 0.86 & 0.84 & 0.84 & 0.84 & 0.86 & 0.85 & 0.83 & 0.88 & 0.83 & 0.86 & 0.86 & 0.85 \\
\hline $\begin{array}{l}\% \text { Limit Orders } \\
\text { (Traders) }\end{array}$ & std & 0.29 & 0.31 & 0.31 & 0.33 & 0.30 & 0.31 & 0.32 & 0.27 & 0.34 & 0.30 & 0.29 & 0.30 \\
\hline
\end{tabular}

Panel B: Survey Respondents

\begin{tabular}{|c|c|c|c|c|c|c|c|c|c|c|c|c|c|}
\hline Month & & Apr-08 & May-08 & Jun-08 & Jul-08 & Aug-08 & Sep-08 & Oct- 08 & Nov-08 & Dec-08 & Jan-09 & Feb-09 & Mar-09 \\
\hline Investors & $\mathrm{N}$ & 787 & 701 & 605 & 557 & 520 & 491 & 650 & 402 & 330 & 312 & 272 & 291 \\
\hline Gender & mean & 0.07 & 0.08 & 0.08 & 0.08 & 0.08 & 0.08 & 0.09 & 0.08 & 0.08 & 0.08 & 0.09 & 0.09 \\
\hline Age & mean & 50.55 & 51.22 & 51.50 & 51.83 & 52.79 & 52.60 & 51.50 & 52.31 & 52.65 & 52.64 & 53.83 & 53.25 \\
\hline Age & std & 13.51 & 13.55 & 13.43 & 13.57 & 12.90 & 13.05 & 13.29 & 13.25 & 12.88 & 12.86 & 12.62 & 12.67 \\
\hline Account Tenure & mean & 3.93 & 3.98 & 4.09 & 3.98 & 4.11 & 4.08 & 4.26 & 4.35 & 4.34 & 4.45 & 4.53 & 4.38 \\
\hline Account Tenure & std & 2.76 & 2.79 & 2.77 & 2.78 & 2.77 & 2.76 & 2.78 & 2.73 & 2.75 & 2.74 & 2.68 & 2.71 \\
\hline Income $€$ & mean & 20,181 & 20,088 & 20,109 & 19,978 & 20,085 & 20,002 & 20,147 & 19,892 & 19,859 & 20,046 & 20,034 & 20,028 \\
\hline Income $€$ & std & 4,285 & 3,956 & 4,240 & 3,729 & 3,835 & 4,153 & 4,197 & 3,808 & 3,543 & 3,897 & 3,844 & 3,860 \\
\hline Portfolio Value $€$ & mean & 54,446 & 54,264 & 45,411 & 45,509 & 49,557 & 39,707 & 29,490 & 33,660 & 30,169 & 30,693 & 27,444 & 27,229 \\
\hline Portfolio Value $€$ & std & $1,43,872$ & $1,44,617$ & $1,28,455$ & $1,28,159$ & $1,24,176$ & $1,05,507$ & $1,00,216$ & $1,18,529$ & 66,600 & 66,198 & 53,089 & 55,039 \\
\hline House Value $€$ & mean & $2,76,690$ & $2,72,969$ & $2,72,038$ & $2,73,559$ & $2,74,221$ & $2,74,736$ & $2,77,543$ & $2,72,429$ & $2,72,020$ & $2,73,443$ & $2,77,193$ & $2,73,037$ \\
\hline House Value $€$ & std & $1,10,125$ & $1,02,015$ & $1,09,290$ & $1,01,943$ & $1,01,006$ & $1,10,771$ & $1,12,864$ & $1,04,787$ & 98,530 & 99,506 & $1,08,672$ & $1,00,576$ \\
\hline Fraction Derivatives & & 0.24 & 0.23 & 0.25 & 0.25 & 0.23 & 0.24 & 0.26 & 0.19 & 0.20 & 0.24 & 0.22 & 0.20 \\
\hline Fraction Traded & & 0.52 & 0.54 & 0.55 & 0.52 & 0.46 & 0.54 & 0.64 & 0.46 & 0.42 & 0.48 & 0.49 & 0.45 \\
\hline Trades (Traders) & mean & 9.23 & 7.08 & 7.94 & 8.40 & 6.68 & 8.54 & 10.79 & 8.66 & 7.23 & 10.20 & 10.08 & 9.72 \\
\hline Trades (Traders) & std & 12.26 & 10.79 & 11.90 & 12.57 & 9.58 & 13.76 & 18.50 & 12.51 & 10.33 & 16.10 & 16.88 & 13.97 \\
\hline Volume $€$ (Traders) & mean & 56,262 & 24,814 & 31,821 & 27,447 & 22,637 & 28,375 & 55,642 & 30,555 & 22,986 & 35,797 & 31,304 & 27,663 \\
\hline Volume $€$ (Traders) & std & $2,42,164$ & 53,239 & 80,947 & 65,300 & 48,199 & 65,511 & $3,59,009$ & 87,480 & 69,731 & 93,522 & 84,222 & 73,659 \\
\hline Turnover (Traders) & mean & 0.65 & 0.43 & 0.49 & 0.57 & 0.36 & 0.50 & 1.10 & 0.86 & 0.47 & 0.56 & 0.70 & 1.00 \\
\hline Turnover (Traders) & std & 1.82 & 1.13 & 1.41 & 1.61 & 0.91 & 1.08 & 4.68 & 2.23 & 1.51 & 1.07 & 2.08 & 3.91 \\
\hline $\begin{array}{l}\% \text { Limit Orders } \\
\text { (Traders) }\end{array}$ & mean & 0.88 & 0.84 & 0.85 & 0.85 & 0.89 & 0.86 & 0.83 & 0.85 & 0.85 & 0.85 & 0.83 & 0.88 \\
\hline $\begin{array}{c}\% \text { Limit Orders } \\
\text { (Traders) }\end{array}$ & std & 0.27 & 0.32 & 0.30 & 0.32 & 0.29 & 0.31 & 0.33 & 0.30 & 0.32 & 0.30 & 0.33 & 0.26 \\
\hline Return Expectation & mean & 4.35 & 4.22 & 3.68 & 3.93 & 4.27 & 3.53 & 3.41 & 3.73 & 3.93 & 4.13 & 3.61 & 4.36 \\
\hline Return Expectation & std & 0.93 & 0.90 & 0.96 & 1.00 & 0.96 & 0.99 & 1.01 & 1.05 & 0.89 & 1.09 & 1.15 & 1.03 \\
\hline Risk Tolerance & mean & 4.03 & 4.02 & 3.64 & 3.90 & 4.08 & 3.71 & 3.85 & 3.97 & 4.03 & 3.95 & 3.98 & 4.04 \\
\hline Risk Tolerance & std & 1.15 & 1.13 & 1.26 & 1.19 & 1.12 & 1.28 & 1.28 & 1.23 & 1.14 & 1.15 & 1.28 & 1.13 \\
\hline Risk Perception & mean & 4.47 & 4.46 & 5.02 & 4.19 & 3.93 & 4.49 & 4.31 & 4.34 & 4.12 & 4.13 & 4.50 & 4.25 \\
\hline Risk Perception & std & 1.66 & 1.64 & 1.96 & 1.14 & 1.11 & 1.15 & 1.31 & 1.28 & 1.21 & 1.21 & 1.35 & 1.20 \\
\hline
\end{tabular}

Note. This table presents monthly summary statistics for the brokerage account data. Panel A refers to all investors for whom brokerage records are available. This sample includes the investors who during the entire sample period participated at least once in the survey and who were not excluded by the sample-selection restrictions as defined in section I. The monthly summary statistics presented in Panel B refer to the subset of the investors who responded to the survey in each respective month. Variables are defined in Table 1. 
TABLE 3

Survey Questions

Survey Variable

Answer Categories

Return Expectation $(1=$ low/pessimistic, $7=$ high/optimistic $)$

Next month, I expect my investments to do less well than desired.

For the next month, I have a positive feeling about my financial future."

Next month, my investments will have a worse performance

than those of most other investors.

Next month, it is unlikely that my investment behavior will lead to positive returns.

For the next month, the future of my investment portfolio looks good.

Risk Tolerance $(1=$ low risk tolerance, $7=$ high risk tolerance $)$

Next month, I prefer certainty over uncertainty when investing.

Next month, I avoid risks when investing.

Next month, I do not like to take financial risks.

Next month, I do not like to "play it safe" when investing.

Risk Perception ( $1=$ low perceived risk, $7=$ high perceived risk)

I consider investing to be very risky next month.

I consider investing to be safe next month.

I consider investing to be dangerous next month. *

I consider investing to have little risk next month.

1 (totally agree)-7 (totally disagree) 1 (totally agree)-7 (totally disagree)

1 (totally agree)-7 (totally disagree)

1 (totally agree)-7 (totally disagree) 1 (totally agree)-7 (totally disagree)

1 (totally agree) -7 (totally disagree) 1 (totally agree)-7 (totally disagree) 1 (totally agree)-7 (totally disagree) 1 (totally agree)-7 (totally disagree)

1 (totally agree)-7 (totally disagree) 1 (totally agree) -7 (totally disagree) 1 (totally agree)-7 (totally disagree) 1 (totally agree)-7 (totally disagree)

Note. This table presents the questions as used in this study's 12 consecutive monthly surveys. A 7-point Likert scale is used to record investors' response to each question. Each survey variable (return expectation, risk tolerance, risk perception) is calculated as the equally weighted average of the respective survey questions (Dillon and McDonald [2001]).

*denotes a reverse-scored question.

survey variables, well above the recommended cut-off level of 0.70 for reliability (Hair et al. [1998]). One-factor solutions of exploratory factor analyses indicate convergent validity. Additional factor analyses show that cross-loadings between the different survey variables are either low or insignificant, confirming their discriminant validity (Nunnally and Bernstein [1994]).

\section{RESULTS}

In this section, we examine how the levels of and changes in investors' perceptions drive their actual trading behavior (decision to trade or not, turnover, average trade size, and derivatives trading) and their actual risk-taking behavior (portfolio risk, buy-sell ratio, and limit order usage). We use panel regressions in which investor perceptions are included as explanatory variables in their one-month lagged levels and changes (revisions) from that month to infer how perceptions at the start of a month subsequently influence behavior. The panel models differentiate the general effect of levels of investor perceptions from specific effects of revisions in their perceptions and resulting behavior. We control for a variety of characteristics that prior literature identified as drivers of investment decisions, such as gender, age, account tenure, income, portfolio value, and house value (see Barber and Odean [2001], Seru, Shumway, and Stoffman [2010], Korniotis and Kumar [2011], van Rooij, Lusardi, and Alessie [2011]). We also control for the possible impact of past aggregate market returns by including time fixed effects. ${ }^{3}$

\section{Investor Perceptions and Trading Behavior}

Table 4 presents results on investors' decision to trade or not, turnover, average trade size, and derivatives usage. Whereas the first two indicators refer to investors' trading activity, the latter two indicators refer to particular decisions taken by investors when they are trading.

Probit regression results (first column in Table 4) show that individual investors' perceptions explain their actual decisions whether to trade or not. In particular, we find that investors are more likely to trade the higher both the levels and upward revisions of their return expectations and risk tolerance, and the higher the level of their risk perceptions. This result extends the findings of previous behavioral finance research which showed that investors' subjective expectations of market risk and returns are positively correlated with their hypothetical portfolio updating decisions (Weber et al. [2013]). The coefficients of the control variables are consistent with the work by Dorn and Huberman [2005]. That is, investors are less likely to trade if they are wealthier (i.e., have a higher portfolio value).

For the subset of investors who trade, higher levels of return expectations and risk perceptions, as well as upward revisions thereto, induce higher turnover (second column in Table 4). Risk tolerance is not significantly linked to turnover once the decision of whether to trade or not is made. The results regarding the control variables are again in line with previous research in behavioral finance. That is, turnover is lower for wealthier investors (i.e., those with larger portfolios or higher house value; (Dorn and Huberman [2005], Bauer et al. [2009]). As to average trade size, we 
TABLE 4

Trading Behavior

\begin{tabular}{|c|c|c|c|c|c|c|c|c|}
\hline \multirow[b]{2}{*}{ Dependent Variable } & \multicolumn{2}{|c|}{ Traded } & \multicolumn{2}{|c|}{ Turnover } & \multicolumn{2}{|c|}{ Avg. Trade Size/1,000 } & \multicolumn{2}{|c|}{ Derivatives } \\
\hline & Marg. Eff. & Std. err. & Coef. & Std. err. & Coef. & Std. err. & Marg. Eff. & Std. err. \\
\hline Return Expectation prev. month & 0.104 & $0.019 * * *$ & 0.035 & $0.020 *$ & 0.666 & 0.540 & 0.068 & $0.031 * *$ \\
\hline$\Delta$ Return Expectation & 0.064 & $0.016^{* * *}$ & 0.031 & $0.017 *$ & 0.464 & $0.275^{*}$ & 0.059 & $0.025 * *$ \\
\hline Risk Tolerance prev. month & 0.076 & $0.016^{* * * *}$ & 0.015 & 0.015 & -0.356 & 0.398 & 0.020 & 0.025 \\
\hline$\Delta$ Risk Tolerance & 0.067 & $0.013 * * *$ & -0.008 & 0.013 & -0.196 & 0.177 & -0.006 & 0.020 \\
\hline Risk Perception prev. month & 0.026 & $0.013 * *$ & 0.032 & $0.012 * * *$ & 0.188 & 0.219 & -0.012 & 0.020 \\
\hline$\Delta$ Risk Perception & 0.015 & 0.010 & 0.026 & $0.009 * * *$ & 0.106 & 0.179 & -0.014 & 0.015 \\
\hline Gender & 0.036 & 0.074 & -0.067 & 0.044 & -0.838 & 0.887 & 0.015 & 0.113 \\
\hline Age & 0.002 & 0.002 & 0.003 & $0.001 *$ & -0.005 & 0.028 & 0.010 & $0.003 * * *$ \\
\hline Account Tenure & -0.005 & 0.007 & 0.011 & 0.006 & 0.004 & 0.146 & 0.047 & $0.011 * * *$ \\
\hline $\ln ($ Income $)$ & 0.259 & 0.188 & 0.247 & 0.161 & 2.908 & 2.669 & 0.010 & 0.292 \\
\hline $\ln$ (Portfolio Value) prev. month & 0.073 & $0.010 * * *$ & -0.065 & $0.012 * * *$ & 1.742 & $0.401 * * *$ & 0.004 & 0.016 \\
\hline $\ln$ (House Value) & -0.196 & $0.094 * *$ & -0.210 & $0.094 * *$ & -0.377 & 1.340 & -0.157 & 0.148 \\
\hline Dividend Choice Stock & -0.025 & 0.055 & 0.152 & $0.051 * * *$ & 0.736 & 0.801 & -0.095 & 0.075 \\
\hline Dividend Choice Cash \& Stock & -0.080 & $0.048 *$ & 0.073 & $0.034 * *$ & 0.369 & 0.827 & -0.056 & 0.070 \\
\hline Constant & & & 0.638 & 0.898 & -40.723 & 16.977 & & \\
\hline Time fixed effects & \multicolumn{2}{|c|}{ YES } & \multicolumn{2}{|c|}{ YES } & \multicolumn{2}{|c|}{ YES } & \multicolumn{2}{|c|}{ YES } \\
\hline N Observations & \multicolumn{2}{|c|}{3,885} & \multicolumn{2}{|c|}{1,914} & \multicolumn{2}{|c|}{1,914} & \multicolumn{2}{|c|}{1,914} \\
\hline N Investors & \multirow{2}{*}{\multicolumn{2}{|c|}{1,041}} & \multicolumn{2}{|c|}{698} & \multicolumn{2}{|c|}{698} & \multicolumn{2}{|c|}{698} \\
\hline $\mathrm{R} 2$ & & & \multicolumn{2}{|c|}{0.108} & \multicolumn{2}{|c|}{0.133} & & \\
\hline
\end{tabular}

Note. This table presents the results from regressions of several indicators of investor trading behavior on investor perceptions and a set of control variables. Dependent variables are market participation (Traded), turnover, average trade size, and derivatives trading. The first and the fourth column shows the results of a random effects panel probit estimation for the dependent variable Traded or Derivatives. Traded indicates whether an investor traded in a particular month (1) or not (0). Derivatives indicates whether an investor traded derivatives in a particular month (1) or not (0) and this regression is performed on the truncated sample of investors who have at least one trade in a particular month. Reported are marginal effects at means (0) of independent continuous (discrete dummy) variables. The number of individual investors included the regression $(1,041)$ is smaller than the sample available for analysis $(1,376)$ because not all investors responded to the survey for two consecutive months. The second and third column show results of linear panel models for the truncated sample of investors who have at least one trade in a particular month. Standard errors are clustered on the investor level for the linear panel models. Variables are defined in Table 1. ${ }^{*}, * * * *$ denote statistical significance at the $10 \%, 5 \%$, and $1 \%$ levels, respectively.

find that upward revisions in return expectations are associated with trading larger amounts per transaction (third column in Table 4). This finding is consistent with prior work on how people's conviction drives their willingness to bet on their own judgments (Heath and Tversky [1991]). Regarding derivatives trading, investors with higher levels and upward revisions of return expectations are more likely to trade these instruments (fourth column in Table 4). Finally, as in Bauer et al. [2009], investors who are older and more experienced are also more likely to trade derivatives. Robustness checks regarding investor-specific past returns show that including them in the regression models does not eliminate the explanatory power of investor perceptions (detailed results available upon request).

The results of this section provide a number of key insights into how investor perceptions drive actual trading behavior. Most importantly, the results extend prior work in behavioral finance that has shown the impact of investor perceptions on hypothetical investment choices by showing that perceptions are also capable of explaining actual trading and risk-taking behavior. In particular, we find that higher levels and upward revisions of return expectations make investors more likely to trade, and when they trade, it increases their turnover, average trade size and likelihood of trading derivatives. Furthermore, higher levels and upward revisions of risk tolerance make investors more likely to trade. Finally, higher levels and upward revisions of risk perceptions make investors more likely to trade, and when they trade, increases their turnover.

\section{Investor Perceptions and Risk-Taking Behavior}

Table 5 shows how investors' perceptions affect three aspects of their actual risk-taking behavior. The first column shows how perceptions affect the standard deviation of returns (higher return standard deviation means riskier portfolios), the second column shows how perceptions affect the buy-sell ratio (higher buy-sell ratios indicate an increased exposure to the stock market), and the third column shows how perceptions affect the usage of limit orders. $^{4}$

As with investors' trading behavior (presented in the third section), we find that investor perceptions are an important driver of their actual risk-taking behavior. That 
TABLE 5

Risk-Taking Behavior

\begin{tabular}{|c|c|c|c|c|c|c|}
\hline \multirow[b]{2}{*}{ Dependent Variable } & \multicolumn{2}{|c|}{ Std(Return) } & \multicolumn{2}{|c|}{ Buy-Sell Ratio } & \multicolumn{2}{|c|}{ Percentage Limit Orders } \\
\hline & Coef. & Std. err. & Coef. & Std. err. & Coef. & Std. err. \\
\hline Return Expectation prev. month & 0.009 & 0.009 & -0.011 & 0.022 & 0.009 & 0.014 \\
\hline$\Delta$ Return Expectation & 0.006 & 0.007 & -0.031 & 0.021 & -0.003 & 0.011 \\
\hline Risk Tolerance prev. month & 0.030 & $0.009 * * *$ & 0.062 & $0.018 * * *$ & 0.020 & $0.010^{* *}$ \\
\hline$\Delta$ Risk Tolerance & 0.013 & $0.005^{* * *}$ & 0.068 & $0.016^{* * *}$ & 0.018 & $0.008 * *$ \\
\hline Risk Perception prev. month & 0.018 & $0.006^{* * *}$ & -0.028 & 0.015 & -0.001 & 0.008 \\
\hline$\Delta$ Risk Perception & 0.007 & $0.004 *$ & -0.012 & 0.013 & 0.000 & 0.006 \\
\hline Gender & -0.023 & 0.021 & 0.024 & 0.060 & 0.030 & 0.058 \\
\hline Age & 0.001 & $0.001 *$ & -0.001 & 0.001 & 0.001 & 0.001 \\
\hline Account Tenure & 0.007 & $0.003 * *$ & -0.012 & $0.006^{*}$ & 0.008 & 0.005 \\
\hline $\ln ($ Income $)$ & 0.074 & 0.057 & -0.152 & 0.176 & -0.029 & 0.092 \\
\hline $\ln$ (Portfolio Value) prev. month & -0.047 & $0.008 * * *$ & 0.000 & 0.000 & 0.000 & 0.007 \\
\hline $\ln$ (House Value) & -0.025 & 0.033 & -0.056 & $0.010^{* * *}$ & 0.015 & 0.053 \\
\hline Dividend Choice Stock & 0.019 & 0.023 & 0.165 & $0.082 * *$ & -0.048 & 0.033 \\
\hline Dividend Choice Cash \& Stock & 0.022 & 0.018 & 0.009 & 0.046 & -0.036 & 0.025 \\
\hline Constant & 0.275 & 0.395 & 0.042 & 1.166 & 0.831 & 0.620 \\
\hline Time fixed effects & \multicolumn{2}{|c|}{ YES } & \multicolumn{2}{|c|}{ YES } & \multicolumn{2}{|c|}{ YES } \\
\hline N Observations & \multicolumn{2}{|c|}{3,885} & \multicolumn{2}{|c|}{1,914} & \multicolumn{2}{|c|}{1,914} \\
\hline $\mathrm{N}$ Investors & \multicolumn{2}{|c|}{1,041} & \multicolumn{2}{|c|}{968} & \multicolumn{2}{|c|}{968} \\
\hline R2 & \multicolumn{2}{|c|}{0.241} & \multicolumn{2}{|c|}{0.081} & \multicolumn{2}{|c|}{0.041} \\
\hline
\end{tabular}

Note. This table presents the results from regressions of risk-taking behavior on investor perceptions and a set of control variables. Dependent variables are the investor-specific standard deviation of daily portfolio returns in a particular month (in monthly terms), the buy-sell ratio, and the monthly percentage of limit orders. The first column show results of linear panel models for the full sample (standard deviation of return), the second and third columns shows results for the truncated sample of investors who have at least one trade in a particular month. The number of individual investors included the first regression (1,041) is smaller than the sample available for analysis $(1,376)$, because not all investors responded to the survey for two consecutive months. Standard errors are clustered on the investor level. Variables are defined in Table $1 .{ }^{*}, * *, * * *$ denote statistical significance at the $10 \%, 5 \%$, and $1 \%$ levels, respectively.

is, both higher past levels of and upward revisions in risk tolerance lead investors to choose portfolios with higher standard deviations. Investors also seem to be aware of the risk that they choose to take, as their risk perceptions are positively associated with the risk of their actual portfolios. The perception regression coefficients (Table 5) are economically significant because monthly standard deviations are examined. For example, a one-point increase in the past level of an investor's risk tolerance increases the annualized standard deviation of his or her investment portfolio by around 10 percentage points. Finally, consistent with prior work in behavioral finance, the results on the control variables show that investors who are more experienced (i.e., those who are older or have a longer account tenure) take on more risk (see, e.g., Barber and Odean [2001], Bauer et al. [2009], Grinblatt and Keloharju [2009]), whereas investors with larger portfolios may better understand and hence be less willing to take risk (see Shefrin [2002]). Regarding willingness to increase their stock-market exposure, we find that investors with higher levels of and upward revisions in risk tolerance, and lower levels of risk perceptions have higher buy-sell ratios. That is, more risktolerant investors incur greater exposure to the stock market, while investors who perceive higher risk lower their exposure to the stock market. In line with research showing that less-sophisticated investors tend to take on more risk than sophisticated investors (see, e.g., Goetzmann and
Kumar [2008]), we find that less-experienced investors (i.e., those with shorter account tenure) have higher buysell ratios. Finally, regarding the usage of limit orders, we find that investors with higher levels of and upward revisions in risk tolerance use limit orders more frequently. That is, consistent with results obtained with simulated trading data by Linnainmaa [2010], more risk tolerant investors seem to be more willing to accept the risk of nonexecution of their orders as they try to gain from the liquidity demand of impatient investors.

Combining the results regarding investors' risk-taking behavior with the earlier results regarding their trading behavior provides an intuitive insight into the effects of investor perceptions on actual trading and risk-taking behavior: Higher levels and upward revisions of risk tolerance make investors more likely to trade, and when they trade, it leads them to increase their buy-sell ratios and limit order usage. In contrast, although higher levels and upward revisions of risk perceptions also make investors more likely to trade, when they trade, it decreases their buy-sell ratios.

\section{CONCEPTUAL FRAMEWORK AND CONCLUSION}

We combine monthly survey data with matching brokerage records to construct a panel dataset showing how the levels 
of and changes in individual investors' perceptions drive their actual trading and risk-taking decisions. Whereas previous work has typically used experiments or surveys to examine how individuals' perceptions affect hypothetical investment choices or self-reported willingness to invest (see, e.g., Wärneryd [1996], Weber and Milliman [1997], Keller and Siegrist [2006], Fellner and Maciejovsky [2007], Nosic and Weber [2010], Bateman et al. [2011], Weber et al. [2013]), we study the relationship between perceptions and behavior in a real decision context. It is important to do so, as the prior experimental results may not generalize outside of the lab (Kühberger et al. [2002]). The results extend prior research in behavioral finance by demonstrating that the levels of and changes (month-tomonth revisions) in investor perceptions are indeed important drivers of actual behavior. In fact, investor perceptions have explanatory power for individual investors' decisionmaking above and beyond characteristics that can be inferred from brokerage records alone, such as investors' age, gender, or portfolio value. Based on the regression results, Figure 1 finally conceptualizes how investors' perceptions affect their trading and risk-taking decisions, thereby summarizing our main results.

We find that investors with higher levels and upward revisions of return expectations are more likely to trade, have higher turnover, trade larger amounts per transaction, and use derivatives. Moreover, investors with higher levels of and upward revisions in risk tolerance are more likely to trade, have higher buy-sell ratios, use limit orders more frequently, and hold riskier portfolios. Finally, investors with higher levels of risk perception are more likely to trade, have higher turnover, have a lower buy-sell ratio, and hold riskier portfolios. Interestingly, higher levels and upward revisions of risk tolerance lead investors to increase their buy-sell ratios, while higher levels and upward revisions of risk perceptions decrease their buy-sell ratios. This result is consistent with the conceptual difference between risk tolerance and risk perception as established in prior literature, and demonstrates how that conceptual difference results in differences in financial market participants' actual behavior (Pennings and Wansink [2004]).

The results of this paper contribute to the literature in behavioral finance by demonstrating how including psychological variables in models of individual decision making leads to a better understanding of the actual behavior of financial market participants. Strong predictors of investor behavior include not only "traditional" risk variables such as risk tolerance and risk perception but also subjective beliefs about expected stock-market returns and changes, which are crucial drivers of trading and risk-taking behavior (Wärneryd [2001]). What remains called for is research examining how investors exactly form and update their return expectations, risk tolerance, and risk perceptions. In particular, what are the underlying factors that trigger changes in these crucial variables (Gerrans, Faff, and Hartnett [2012], Hoffmann and Post [2014])? This question is

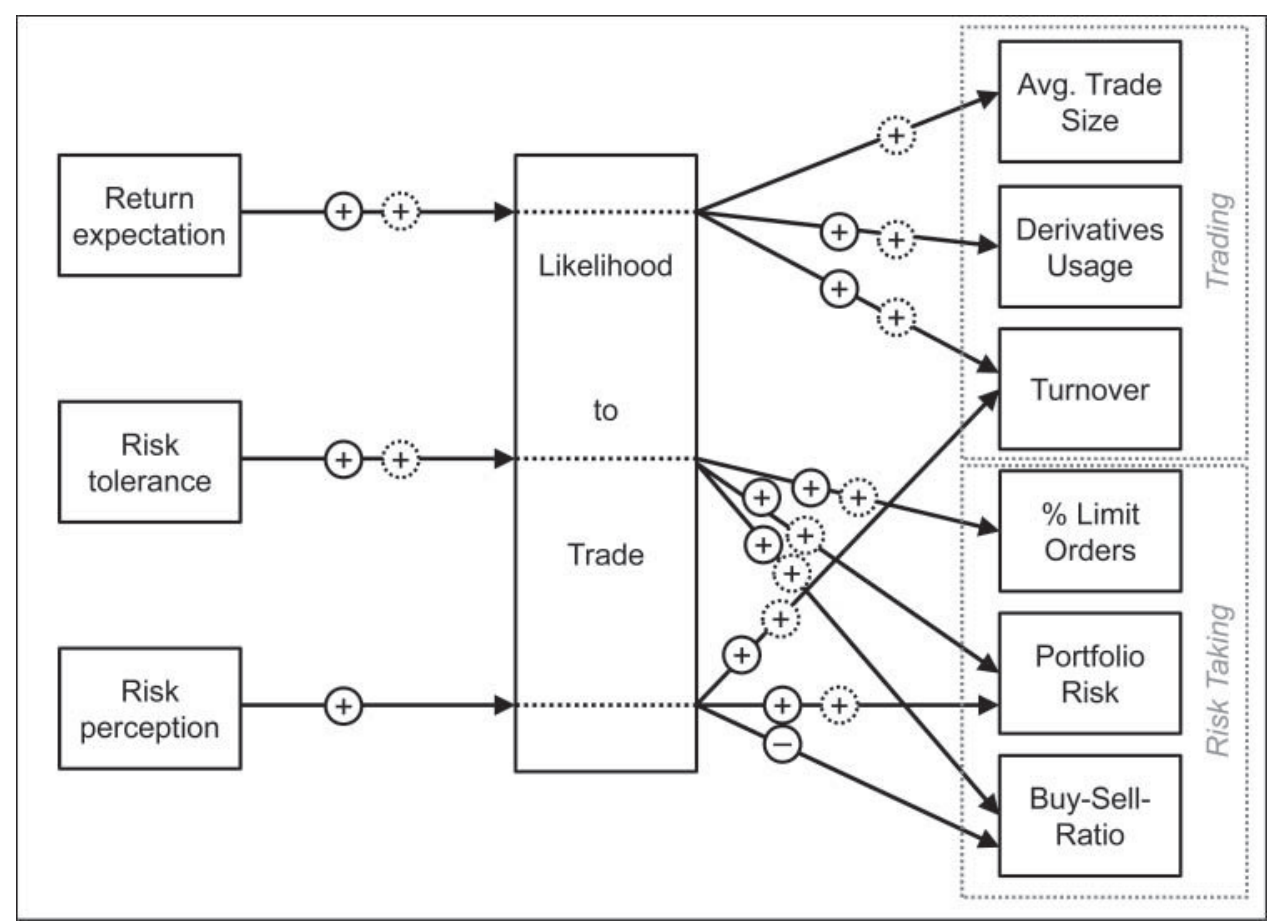

FIGURE 1 How Investor Perceptions Drive Actual Trading and Risk-taking Behavior. Note. This figure presents a conceptual framework of individual investors' trading and risk-taking behavior based on the results from the regressions. Circles with solid lines indicate significant relationships between the levels of perceptions and trading and risk-taking variables, whereas circles with dashed lines refer to changes in perceptions. 
especially important considering that research in behavioral finance and economic psychology considers such changes to be vital in assessing the behavior of individual market participants (Rabin [2002]).

\section{ACKNOWLEDGMENT}

The authors thank a large discount brokerage firm for making available the data used in this study. Moreover, the authors thank the employees of this brokerage firm for their help in answering numerous questions about the data.

\section{NOTES}

1. Whenever we do not specifically refer to return expectations, risk tolerance, or risk perceptions, the term "perceptions" is used to refer to these survey variables in a general way and set them apart from the brokerage data.

2. Home ownership rates are high in the Netherlands (67.5\%, as of 2008; Eurostat [2011]), as well as skewed toward wealthier households (Rouwendal [2007]). Thus, it is likely that the imputed house values correspond closely to the value of the houses actually owned by the investors in the sample.

3. Standard errors are clustered on the investor level. Alternatively, we use Driscoll and Kraay [1998] standard errors. Results in the latter specification are very similar in terms of coefficient significance (detailed results available upon request), that is, the time fixed effect is picking up potential cross-sectional correlation.

4. The investors in the sample primarily trade equity and derivatives. Changes in the buy-sell ratio thus do not measure shifts to different asset classes, but indicate changes in investor's exposure to the market.

\section{REFERENCES}

Antonides, G. and N. L. Van der Sar. "Individual Expectations, Risk Perception and Preferences in Relation to Investment Decision Making." Journal of Economic Psychology, 11, (1990), pp. 227-245.

Barber, B. M. and T. Odean. "Trading is Hazardous to Your Wealth: The Common Stock Investment Performance of Individual Investors." Journal of Finance, 55, (2000), pp. 773-806.

Barber, B. M. and T. Odean. "Boys Will Be Boys: Gender, Overconfidence, and Common Stock Investment." Quarterly Journal of Economics, 116, (2001), pp. 261-292.

Bateman, H., J. Louviere, S. Satchell, T. Islam, and S. Thorp. "Retirement Investor Risk Tolerance in Tranquil and Crisis Periods: Experimental Survey Evidence." Journal of Behavioral Finance, 12, (2011), pp. 201218.
Bauer, R., M. Cosemans, and P. M. A. Eichholtz. "Option Trading and Individual Investor Performance." Journal of Banking and Finance, 33, (2009), pp. 731-746.

Dillon, W. R. and R. McDonald. "How to Combine Multiple Items into a Composite Score." Journal of Consumer Psychology, 10, (2001), pp. 62-64.

Dorn, D. and G. Huberman. "Talk and Action: What Individual Investors Say and What They Do." Review of Finance, 9, (2005), pp. 437-481.

Dorn, D. and P. Sengmueller. "Trading as Entertainment?" Management Science, 55, (2009), pp. 591-603.

Driscoll, J. C. and A. C. Kraay. "Consistent Covariance Matrix Estimation with Spatially Dependent Panel Data." Review of Economics and Statistics, 80, (1998), pp. 549-560.

Eurostat. Distribution of Population by Tenure Status, Type of Household and Income Group. (2011). Retrieved from http://appsso.eurostat.ec. europa.eu/nui/show.do?dataset=ilc_lvho02\&lang=en.

Fellner, G. and B. Maciejovsky. "Risk Attitude and Market Behavior: Evidence from Experimental Asset Markets." Journal of Economic Psychology, 28, (2007), pp. 338-350.

Gerrans, P., R. Faff, and N. Hartnett. "Individual Financial Risk Tolerance and the Global Financial Crisis." Working Paper. University of Western Australia (2012)

Goetzmann, W. N. and A. Kumar. "Equity Portfolio Diversification." Review of Finance, 12, (2008), pp. 433-463.

Grinblatt, M. and M. Keloharju. "Sensation Seeking, Overconfidence, and Trading Activity." Journal of Finance, 64, (2009), pp. 549-578.

Guiso, L., P. Sapienza, and L. Zingales. "Time Varying Risk Aversion." National Bureau of Economic Research, Working Paper (2011).

Hair, J. F., R. E. Anderson, R. L. Tatham, and W. C. Black. Multivariate Data Analysis. Englewood Cliffs, NJ: Prentice Hall, 1998.

Heath, C. and A. Tversky. "Preference and Belief: Ambiguity and Competence in Choice under Uncertainty." Journal of Risk and Uncertainty, 4, (1991), pp. 5-28.

Hoffmann, A. O. I. and T. Post. "How Return and Risk Experiences Shape Investor Beliefs and Preferences." Working Paper. Maastricht University (2014).

Hoffmann, A. O. I., T. Post, and J. M. E. Pennings. "Individual Investor Perceptions and Behavior during the Financial Crisis." Journal of Banking and Finance, 37(1), (2013), pp. 60-74.

Kapteyn, A. and F. Teppa. "Subjective Measures of Risk Aversion, Fixed Costs, and Portfolio Choice." Journal of Economic Psychology, 32, (2011), pp. 564-580.

Keller, C. and M. Siegrist. "Investing in Stocks: The Influence of Financial Risk Attitude and Values-Related Money and Stock Market Attitudes." Journal of Economic Psychology, 27, (2006), pp. 285-303.

Korniotis, G. M. and A. Kumar. "Do Older Investors Make Better Investment Decisions?" Review of Economics and Statistics, 93, (2011), pp. 244-265.

Kühberger, A., M. Schulte-Mecklenbeck, and J. Perner. "Framing Decisions: Hypothetical and Real." Organizational Behavior and Human Decision Processes, 89(2), (2002), pp. 1162-1175.

Linnainmaa, J. T. "Do Limit Orders Alter Inferences about Investor Performance and Behavior?" Journal of Finance, 65, (2010), pp. 1473-1506.

McInish, T. H. and R. K. Srivastava. "The Nature of Individual Investors' Heterogeneous Expectations." Journal of Economic Psychology, 5, (1984), pp. 251-263.

Merkle, C. and M. Weber. "Do Investors Put Their Money Where Their Mouth Is? Stock Market Expectations and Investing Behavior." Journal of Banking and Finance, 46, (2014), pp. 372-386.

Netemeyer, R. G., W. O. Bearden, and S. Sharma. Scaling Procedures: Issues and Applications. Thousand Oaks, CA: Sage Publications, 2003.

Nosic, A. and M. Weber. "How Riskily Do I Invest? The Role of Risk Attitudes, Risk Perceptions, and Overconfidence." Decision Analysis, 7, (2010), pp. 282-301. 
Nunnally, J. C. and I. H. Bernstein. Psychometric Theory. New York: McGraw-Hill, 1994.

Pennings, J. M. E. and A. Smidts. "Assessing the Construct Validity of Risk Attitude." Management Science, 46, (2000), pp. 1337-1348.

Pennings, J. M. E. and B. Wansink. "Channel Contract Behavior: The Role of Risk Attitudes, Risk Perceptions, and Channel Members' Market Structures." Journal of Business, 77, (2004), pp. 697-723.

Rabin, M. "A Perspective on Psychology and Economics." European Economic Review, 46, (2002), pp. 657-685.

Rouwendal, J. "Mortgage Interest Deductibility and Homeownership in the Netherlands." Journal of Housing and the Build Environment, 22(4), (2007), pp. 369-382.

Seru, A., T. Shumway, and N. Stoffman. "Learning by Trading." Review of Financial Studies, 23(2), (2010), pp. 705-739.

Shefrin, H. Beyond Greed and Fear. Understanding Behavioral Finance and the Psychology of Investing.Oxford: Oxford University Press, 2002.
Slovic, P. "Differential Effects of Real versus Hypothetical Payoffs on Choices Among Gambles." Journal of Experimental Psychology, 80(3), (1969), pp. 434-437.

van Rooij, M., A. Lusardi, and R. Alessie. "Financial Literacy and Retirement Planning in the Netherlands." Journal of Economic Psychology, 32 (4), (2011), pp. 593-608.

Wärneryd, K.-E. "Risk Attitudes and Risky Behavior." Journal of Economic Psychology, 17(6), (1996), pp. 749-770.

Wärneryd, K.-E. Stock Market Psychology: How People Value and Trade Stocks. Northampton, MA: Edward Elgar Publishing, 2001.

Weber, E. U. and R. A. Milliman. "Perceived Risk Attitudes: Relating Risk Perception to Risky Choice." Management Science, 43(2), (1997), pp. 123-144.

Weber, M., E. U. Weber, and A. Nosic. "Who Takes Risks When and Why: Determinants of Changes in Investor Risk Taking," Review of Finance, 17(3), (2013), pp. 847-883. 